Maurer F. (2021) Business Intelligence and Innovation: A Digital Innovation Hub as Intermediate for Service Interaction and System Innovation for Small and MediumSized Enterprises. In: Camarinha-Matos L.M., Boucher X., Afsarmanesh H. (eds) Smart and Sustainable Collaborative Networks 4.0. PRO-VE 2021. IFIP Advances in Information and Communication Technology, vol 629. Springer, Cham. https://doi.org/10.1007/978-3-030-85969-5_42

\title{
Business Intelligence \& Innovation: A Digital Innovation Hub as Intermediate for Service Interaction and System Innovation for Small and Medium-sized Enterprises
}

\author{
Florian Maurer \\ Vorarlberg University of Applied Sciences, \\ Department Business Informatics, \\ Hochschulstraße 1, \\ 6850 Dornbirn, Austria \\ florian.maurer@fhv.at
}

\begin{abstract}
Digital Innovation Hubs are a policy instrument of the European Commission to keep with the speed of the digital transformation within the European economy (especially small- and medium-sized enterprises, mid-caps). Within this article, the Digital Innovation Hub on Business Intelligence \& Innovation within the region of the Federal State of Vorarlberg is presented and a possible network of collaborators and co-creators get introduced. In doing so, the academic discipline of Service Science - Service-Dominant Logic - is presented as theoretical manifestation. The contextual embedment of this article at hand is in the European Commission's Digitising European Industry Strategy (2016) and European Industrial \& Digital Strategies (2020). Based on these, a collaborative network of collaborators and co-creators for the Digital Innovation Hub on Business Intelligence \& Innovation to increase service interaction and system innovation get introduced.
\end{abstract}

Keywords: Digital Innovation Hub, Business Intelligence \& Innovation, Service Science, Network Collaboration,

\section{Introduction}

European economy run the risk to lack the digitization of its systems [1]. As highlighted by the European Commission (2021), around 60\% of large industries and more than $90 \%$ of small- and medium-sized enterprises lag behind in digital innovation [2]. The willingness of the managers and organizational decision makers to go with the digital transformation, as explored empirically, is high. But also, due to limited resources and missing interorganizational system interaction and service innovation, the organizations run the risk to miss the implementation of the Industry 4.0 technologies into systems [3].

No organization can innovate in isolation and (European) Digital Innovation Hubs (DIH), a policy instrument of the European Commission, play an important role 
within this field of collaborative innovation. DIHs are designed to build up of structured relationships with, for example, regional authorities, industrial clusters, SME associations, incubators, accelerators, chambers of commerce, etc. Their task is to bring together the stakeholders among the supply- and value-chain for open and collaborative innovation, incl. co-creation of value, testing and experimentation.

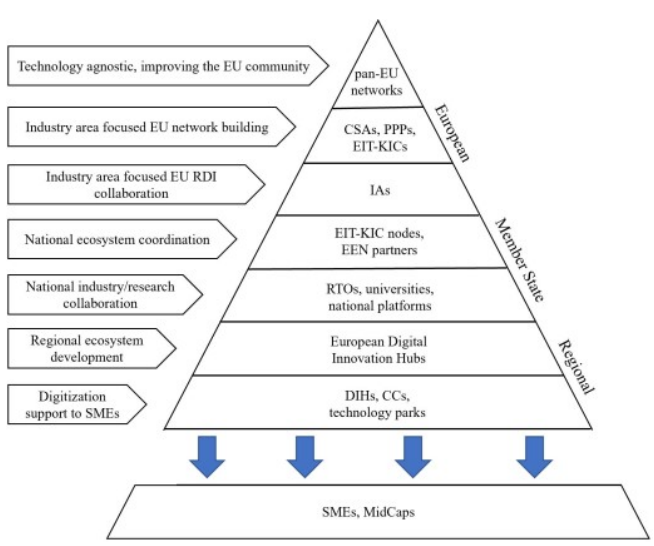

Fig. 1. Getting a view on EDIHs and EU-networks [4] (source: own representation)

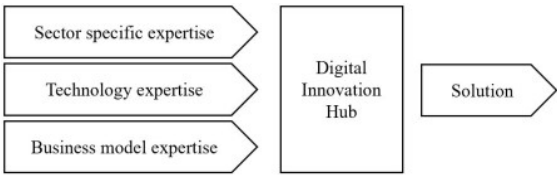

Fig. 2. Digital Innovation Hub Model [5] (source: own representation)

As exemplified in figure $1 \& 2$, there are a variety of perspectives to design and develop a network of collaborators and co-creators for a Digital Innovation Hub. This variety motivates and inspires us to develop a regional ontology of co-creators for the Digital Innovation Hub on Business Intelligence \& Innovation within the Federal State of Vorarlberg.

The research originates within the guidance of the European Commission: to be a critical actor of the regional/national innovation ecosystem, a DIH needs to establish and maintain partnerships with actors with complementary competencies and specializations on a regional, national and European level [6] \& [7].

The structure of this research is built-upon the research question on how a Digital Innovation Hub as intermediate for service interaction and system innovation for small and medium-sized enterprises within the Federal State of Vorarlberg can look like. In particular: who are the (possible) stakeholders of the Digital Innovation Hub on Business Intelligence \& Innovation and what are their activities and tasks?

This article is composed of four chapters. Chapter 1 introduces the research problem, research motivation and research question. Chapter 2 investigates into related works on cooperation and collaboration in networks. This chapter presents the Service-Dominant Logic as theoretical manifestation and the Digital Innovation Hub initiative (service science in action) as contextual embedment. Focus within chapter 2 is on the activities and tasks out of theoretical manifestation on service science and in the contextual embedment of the Digital Innovation Hub policy initiative. Chapter 3 investigates into regional, national and European network collaborators and cocreators for the Digital Innovation Hub on Business Intelligence \& Innovation. Chapter 4 concludes the article and provides a future outlook in development of intended DIH for Business Intelligence \& Innovation. 


\section{Related Works on Cooperation and Collaboration in Networks}

This chapter investigates into the question on what the activities and tasks of the Hub stakeholders are. As presented in section 2.1, the theoretical manifestation of this article at hand origins in the academic discipline of Service Science. The contextual embedment (c.f. section 2.2) roots in the European Commission's Digitising European Industry Strategy (2016) and European Industrial \& Digital Strategies (2020).

\subsection{The Academic Discipline of Service Science}

The academic discipline of Service Science (e.g. [8], [9], [10]) is a theory to increase service interaction and value co-creation mechanism among heterogenous system stakeholders. Main streams of research are the Service-Dominant Logic (SDL) (pioneering articles: [11], [12], [13]), Service Science, Management, Engineering and Design (SSMED) [14], Viable Systems Approach [15] and Work System Theory [16]. It is an interdisciplinary field of research and is about the science of service, service systems and service ecosystems as well as how service systems interact and co-create value [17]. The general aim of Service Science is to increase customer centricity and to enable enhanced levels of service innovation. It considers (collaborative, open) service innovation (e.g. technological innovation) as most important trigger for service system engineering and evolution. Especially in Germany, service (system) engineering and innovation has a long tradition. For example, the articles of Ganz (2006), the work group "Evaluation Service Science" [19] and Böhmann, Leimeister, \& Möslein (2014) could be identified as pioneering works.

The concept of SDL, according to Maglio \& Spohrer (2007), builds the philosophical/theoretical foundation for the general theory of Service Science. It was firstly introduced and published by Vargo \& Lusch in 2004 [11], [12] and investigates into the shift from Good-Dominant Logic to increased service thinking and thinking systems in service. SDL emphasizes to move forward "ordinary" service management: service can be provided through a good but service are superordinate to goods - not substitutes. Service, in this perspective, are the common dominator of social and economic exchange. Service, in this context, are considered as a "framework for thinking about value creation, rather than a support activity" [22]. SDL has a strong emphasis on service interactions, value co-creation and marketing methods such as, for example, customer relationship management and many-to-many marketing. Core constructs of the SDL are Service, Value, System, Interaction, Resources.

Service: SDL associate service (singular) as a (collaborative) process of serving [23] - doing something for and/or with another service system (entities; relationships and collaborations) to create holistic service experience satisfaction.

Value: Value co-creation principle is existential part of SDL [23]. Value is always co-created and thus SDL is inherently customer-centric. Value, thus, is assimilated by existing and new knowledge and is influenced by the service environment [23], [24].

System: SDL considers service systems as networks of multiple, loosely-coupled and specialized actors that integrate, apply and transform resources. Service systems act in 
service ecologies - "a spontaneously sensing and responding spatial and temporal structure of largely loosely coupled, value-proposing social and economic actors" [25]. These value-creation networks contribute to value co-creation, co-production and exchange of service offerings.

Interaction: SDL bases on service interactions manifested in collaborative communication (among multiple service systems) and learning via exchange (e.g. feedback loops).

Resources: "At the heart of Service-Dominant Logic is the transfer and sharing of resources" [23]. If a resource contributes to a specific outcome/benefit, this process then is called resourcing (e.g. resource creation, integration and resistance removal) [26], [23].

\subsection{Service Science in Action: Digital Innovation Hubs}

With this article at hand, a Digital Innovation Hub (DIH) is considered as a special case of a service system. DIHs are to increase collaboration in networks, service interaction and system innovation. A DIH is either a single organization or a coordinated group of organizations (a heterogenous group of actors and constellations [27]) that complement each other with knowledge, best-practice and expertise [1]. A DIH should act as service center of a digital innovation ecosystem and shall provide access to services, facilities and expertise to a wide range of stakeholders [6]. Stakeholders of a DIH, for example, are: public administrations, national and regional authorities, clusters, incubators, chambers of commerce, industry associations, etc. [6].

As presented by the European Commission, DIHs are a policy instrument to support the regional innovation ecosystem in the themes of digital transformation and digitization of existing business and industry [28], [27]. The purposes of DIHs are to bring together industry, businesses and administrations [1]; to foster business growth, to upgrade local suppliers, to export/transfer specialization to SMEs [28]; to better organize the innovation support system in the region, to make the system more transparent, to communicate more clearly to potential beneficiaries [27]). DIHs foster interregional and international cooperation across the European Union (and beyond, e.g. Africa) and can function as co-designers or advisors of local smart specialization strategies [6] by, for example, provision of information and (specialized) knowledge for decision makers [27]. DIHs than facilitate knowledge exchange, learning and share of good practices between European regions and are engaged in benchmarking. DIHs are diverse organizations and range from regional bodies to clusters or research centers. Their geographical focus can be regional or beyond [28]. Usually a DIH has local functions and European functions [1]: at the local level, DIHs are embedded into local economy and build ecosystems by bringing into contact actors along the value chain; at the European level, DIHs can connect different ecosystems together by identifying innovation opportunities for users and suppliers coming from different regions.

A DIH is a flexible organization and should be based on regional needs and existing capabilities [27] and works with experimentation and co-creation mechanisms [28]. DIHs can also be important partners for strategy development [28]. As depicted in 
table 1, DIHs provide four main services and a sub-set of support services for their clients to access knowledge, methods and software, technology platforms, prototyping solutions and testing facilities [1], [6], [29].

Table 1. Main services and sub-services of a Digital Innovation Hub (Sources: [1], [6], [29])

\begin{tabular}{|l|l|}
\hline Main services & Sub-services \\
\hline Test before invest & $\begin{array}{l}\text { E.g. awareness raising, digital maturity assessment, demonstration activities, visioning for } \\
\text { digital transformation, fostering the integration, adaptation and customisation of various } \\
\text { technologies, testing and experimentation with digital technologies (software and hardware), } \\
\text { knowledge and technology transfer.:(software and hardware [6]) }\end{array}$ \\
\hline $\begin{array}{l}\text { E.g. advertising, hosting or providing of training, boot-camps, traineeships, as well as } \\
\text { supporting the implementation of the short-term advanced digital skills training courses and } \\
\text { job placements [6] }\end{array}$ \\
\hline $\begin{array}{l}\text { Support to find } \\
\text { investments }\end{array}$ & $\begin{array}{l}\text { Intermediate: access to follow up finance to bring the results of testing and experimentation } \\
\text { to the next phase; e.g. access to financial institutions and investors, supporting the use of } \\
\text { InvestEU and other relevant financing mechanisms (e.g. Enterprise Europe Network) [6] }\end{array}$ \\
\hline $\begin{array}{l}\text { Innovation } \\
\text { ecosystem \& } \\
\text { networking }\end{array}$ & $\begin{array}{l}\text { Brokerage function/matchmaking between the needs of organizations and suppliers: } \\
\text { provision of structured relationships with regional authorities, industrial clusters, SME } \\
\text { associations, business development agencies, incubators, accelerators, EEN, EIT co-location } \\
\text { centers, and chambers of commerce [6] }\end{array}$ \\
\hline
\end{tabular}

A DIH, at least, should cover the technology side and the business development side. However, DIHs go beyond borders and supply local industry with highly competitive services [28], connect DIHs from different regions that can provide companies the complementary knowledge they need [27], coordinate the collaboration between actors in the ecosystem and foster networking and matchmaking, either directly by organizing or by participating in events, or through information on the web [27].

\section{Business Intelligence \& Innovation: Network Collaboration}

This chapter investigates into the question on who the (possible) stakeholders are for the DIH on Business Intelligence \& Innovation. To better understand the economic system and the ecosystem's stakeholders within the Hub's region, section 4.1 presents the economic demography of the Federal State of Vorarlberg. Sections 3.2-3.5 investigate into the possible network of collaborators and co-creators. 
Table 2. Activities and tasks assigned to the hub stakeholders (Quadruple Helix Stakeholders)

\begin{tabular}{|c|c|c|c|c|c|}
\hline \multirow{2}{*}{$\begin{array}{c}\text { Dimen-- } \\
\text { sion }\end{array}$} & \multirow[b]{2}{*}{ Activities and tasks } & \multicolumn{4}{|c|}{ Hub stakeholders (Quadruple Helix) } \\
\hline & & \begin{tabular}{|c|} 
Business \& \\
industry
\end{tabular} & $\begin{array}{l}\text { Government \& } \\
\text { public } \\
\text { administration }\end{array}$ & $\begin{array}{c}\text { Civil society \& } \\
\text { users }\end{array}$ & $\begin{array}{l}\text { Research \& } \\
\text { eduction }\end{array}$ \\
\hline \multirow{3}{*}{ 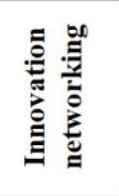 } & Cooperation \& collaboration & $\mathbf{X}$ & $(\mathrm{x})$ & $(\mathrm{x})$ & $(\mathrm{x})$ \\
\hline & $\begin{array}{l}\text { Customer relationship management \& } \\
\text { marketing }\end{array}$ & $\mathbf{X}$ & & & (x) \\
\hline & $\begin{array}{l}\text { International cooperation \& } \\
\text { collaboration }\end{array}$ & (x) & & & $\mathbf{X}$ \\
\hline \multirow{2}{*}{ 为照 } & $\begin{array}{l}\text { Learning, knowledge sharing, best } \\
\text { practice, expertise }\end{array}$ & (x) & & (x) & $\mathbf{X}$ \\
\hline & Resourcing, sharing of resources & $\mathbf{X}$ & $(\mathrm{x})$ & & $(\mathrm{x})$ \\
\hline \multirow{4}{*}{ 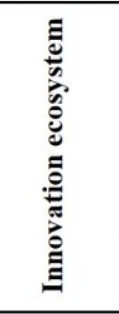 } & $\begin{array}{l}\text { Service system / ecosystem science: } \\
\text { Service-Dominant Logic }\end{array}$ & (x) & & & $\mathbf{X}$ \\
\hline & $\begin{array}{l}\text { Service environment: customer } \\
\text { centricity \& requirements }\end{array}$ & $\mathbf{X}$ & & (x) & (x) \\
\hline & $\begin{array}{l}\text { Service interaction \& (digital) } \\
\text { innovaton }\end{array}$ & (x) & (x) & (x) & $\mathbf{X}$ \\
\hline & $\begin{array}{l}\text { Value co-creation, service experience } \\
\& \text { satisfaction }\end{array}$ & (x) & (x) & (x) & $\mathbf{X}$ \\
\hline \multirow{4}{*}{ 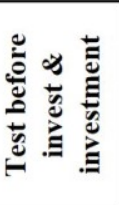 } & Smart specialization & & $\mathbf{X}$ & & $(\mathrm{x})$ \\
\hline & System engineering and evolution & $\mathbf{X}$ & $(\mathrm{x})$ & $(\mathrm{x})$ & $(\mathrm{x})$ \\
\hline & Innovation support system & $(\mathrm{x})$ & & & $\mathbf{x}$ \\
\hline & $\begin{array}{l}\text { Intermediate investments, innovation } \\
\text { funding }\end{array}$ & (x) & $\mathbf{X}$ & & (x) \\
\hline
\end{tabular}

As depicted in table 2 and presented in the following sections, 57 network collaborators and co-creators within the region of Vorarlberg and beyond could be identified. These stakeholders are clustered among the Quadruple Helix Stakeholders: business \& industry, government \& public administration, civil society \& users and research \& education. Furthermore, the stakeholders are assigned to the identified activities and tasks out of the theoretical manifestation and the contextual embedment.

\subsection{Demography and Economic System of the Federal State of Vorarlberg}

The Federal State of Vorarlberg/Austria is embedded into the international region of the Lake of Constance. It is surrounded by the countries of Liechtenstein and Switzerland in the West, Germany (Baden-Württemberg, Bavaria) in the North and Tyrol (Austria) in the East. At the cut-off date of $31^{\text {st }}$ March 2020, Vorarlberg was home to 427.758 citizens (398.657 main residences, 29.101 second residences). Vorarlberg count 161.629 dependent employees and 16.915 commuters to Liechtenstein and Switzerland. Vorarlberg is one of the strongest economic regions in Europe. The basis of the economic power is an above-average level of industrialization, coupled with competitive trade and export, numerous innovative enterprises and a strong tourism industry. The export/import quota is positive - 
Vorarlberg exports more than it imports (10.691 Mio Euro export vs. 7.930 Mio EUR import). Main trade partners are Germany, Switzerland, Italy and France. Vorarlberg is a highly active region in the field of innovation. For example, in 2019, 116 patents out of the region have been filed to the Austrian Patent Office. The Government of the Federal State of Vorarlberg committed itself to five smart specialization strategies that are Smart Textiles, Energy- and Energy Efficiency, Human and Technology, Education and Health and Intelligent Production. In doing so, the Government released several lighthouse projects and innovation projects. Based on a survey about digital transformation in enterprises, 93\% of interviewed managers within Vorarlberg expect impacts caused by technological change and digital transformation.

\subsection{Network Collaborators and Co-creators Out of Business \& Industry}

Business- and industry: at the level of associations for business and industry relevant stakeholders are the Wirtschaftsstandort Vorarlberg GmbH (WISTO), Chancenland Vorarlberg, the Vorarlberg chamber of commerce and its youth organization (Junge Wirtschaft Vorarlberg) as well as the Vorarlberg federation of industries (IV) and its youth organization (Junge Industrie Vorarlberg). WISTO supports and grants industrial and entrepreneurial innovation projects as well as organizes Chancenland Vorarlberg: a platform to recruit knowledge workers for the Vorarlberg labor market. The Vorarlberg chamber of commerce represents the interests of business and entrepreneurs within the region. The Vorarlberg federation of industries represents the interests of the industry. The Junge Wirtschaft and the Junge Industrie - the youth organizations of the Vorarlberg chamber of commerce and the Vorarlberg federation of industries - represent the interest of young entrepreneurs and start-up organizations within business and industry. For example, an initiative of the Junge Wirtschaft that could be relevant for the Hub is Startupland. It provides a platform for entrepreneurs and start-ups and is active in networking and interest representation. The business association Vorarlberg, the Vorarlberger trade association, the Export Club Vorarlberg and the Marketing Club Vorarlberg could be identified as further stakeholders out of business and industry. These organizations are to support and to lobby for the economic objects of business.

Thematic associations: the Logistic Research Austria, the Verein Netzwerk Logistik, its regional branch Verein Netzwerk Logistik Region West and the platform Industrie 4.0 are identified as network co-creators. Logistic Research Austria is an association composed of universities (of applied sciences) within Austria that investigates into the fields of logistics and supply chain management. The Verein Netzwerk Logistik is Austria's largest industrial business network in the field of logistics and supply chain management. It has several branches within Austria (incl. Vorarlberg: Verein Netzwerk Logistik Region West) and beyond (e.g. Switzerland).

(Private) initiatives: there are a variety of (private) initiatives within the region of Vorarlberg. These are, for example, Platform $\mathrm{V}$ and the Platform for Digital Initiatives. Platform V aims to provide an industrial platform for collaborative design and engineering of disruptive and digital business models. The Platform for Digital Initiatives is an association for (young) innovators and provides a maker-space for 
business, industry and society. A further relevant stakeholder could be Interactive West. It is the largest conference on digital transformation within the region of the Lake of Constance. The platform Industrie 4.0 is a national initiative to bring together business, industry, politics and academia and to discuss the emergent trends and technologies within the field of the digital transformation.

\subsection{Network Collaborators and Co-creators Out of Government \& Public Administration}

The Government of the Federal State of Vorarlberg could be identified as primary stakeholder from the field of politics and government for the DIH on Business Intelligence \& Innovation. The government is the owner of the Vorarlberg University of Applied Sciences. Based on the "Verordnung des Landeshauptmannes über die Geschäftseinteilung des Amtes der Vorarlberger Landesregierung (ALReg-GE)", departments of special interest are the departments for European Affairs (\$2 ALRegGE Art. c)), Science and Education (§4 ALReg-GE Art. b), Gruppe II) and General Economic Affairs ( $\$ 8$ ALReg-GE Art. a), Gruppe VI). Further important co-creators at governmental level are the Federal Ministries of the Republic Austria for (1) Education, Science and Research, (2) Digital and Economic Affairs and (3) Climate Action, Environment, Energy, Mobility, Innovation and Technology. These ministries enable the connection to a broad variety of accompanied stakeholders from Austria, Europe and Global.

\subsection{Network Collaborators and Co-creators Out of Civil Society \& Users}

Newspapers and journals that are relevant for the Hub on Business Intelligence \& Innovation are Wirtschaftszeit, Die Wirtschaft and Thema Vorarlberg. These are tailored newspaper for managers, decision makers and accompanied stakeholders out of the field of executive management, marketing, controlling, manufacturing, HR, etc. Furthermore, Die Wirtschaft and Thema Vorarlberg are newspaper of the Vorarlberg chamber of commerce and deal with topics out of business, industry and economy - at both: operational and visionary/philosophical level. NEUE and Vorarlberg Nachrichten are daily newspapers within the region and supply the citizens in Vorarlberg with current news out of politics, economics, technology, environment, social, legislative, culture, etc. Taken together, NEUE and Vorarlberg Nachrichten maintain a market coverage of almost $95 \%$. Relevant for the Hub on Business Intelligence \& Innovation are Der Standard and Die Presse too. These are national newspapers and maintain a large section for science and innovation.

Beyond the region of Vorarlberg: relevant stakeholders outside the region, as identified, are the consortium of the Interreg Central Europe projects 4Steps, CEUP, Chain Reactions and ECOS4IN. The consortiums could complement with additional, tailored knowledge, expertise and services. A further important initiative is DIHNET.eu, a project that aims to create a pan-European network of Digital Innovation Hubs. A stakeholder from the European Commissions level is the Smart Specialization Platform. This platform captures the tools and instruments to boost 
smart specialization in the Union's region, incl. the (European) Digital Innovation Hubs.

\subsection{Network Collaborators and Co-creators Out of Research \& Education}

At regional level, the Vorarlberg University of Applied Science (FHV) and its heterogenous departments and institutions, Schloss Hofen and V-Research as well as WIFI Vorarlberg and the Volkshochschule could be identified. The Vorarlberg University of Applied Science is composed of heterogenous research departments and faculties. These are, for example, the research department Business Informatics (that is the operator of the $H u b$ ), the research department Digital Factory and the faculty Business \& Economics as well as the study courses on Digital Innovation (Bachelor), Informatics (Bachelor, Master) and International Business Management (Bachelor, Master) as well as the formats of Blickpunkt Wirtschaft and Business Summit. Additional stakeholder is FHV's startupstube and FHV's Alumni network. The StartupStube is a support organization for students, scholars, young entrepreneurs and innovators to bring an innovation to the market. The Alumni network consists of people that graduated at the FHV and now are successfully working in business and industry. Schloss Hofen is an education- and training center at academic level. It provides several academic courses for further qualification and specialization (e.g. business and law, human science, health, social, etc.). V-Reserach is a non-university center of excellence for applied research, development and innovation. WIFI Vorarlberg and the Volkshochschule Vorarlberg are providers for vocational education and training. For example, WIFI Vorarlberg offers more than 1.800 courses and seminars within a variety of fields related to management, leadership, business, trade, traffic, etc.

Scholarly networks and conferences: a primary stakeholder out of the field of scholarly networks with the region of Vorarlberg is the International BodenseeHochschule. This is an international network of universities (of applied sciences) within the regions of Alpine-Rhine and the Lake of Constance. It enables scientific exchange among the networking universities. A further relevant stakeholder is the Long Night of Research. The Long Night of Research is a tailored event to connect science with stakeholders from politics, society, industry and business.

\section{Findings and Conclusion}

The scientific discipline of Service Science and the European Commission's strategies on Digitising European Industry has been reviewed as basis for the design and development of an ontology of co-creators for the Digital Innovation Hub on Business Intelligence \& Innovation. The Hub shall act as intermediate for increased service interaction and system innovation within the regional innovation system. Service Science, as identified, provides the philosophical/theoretical foundation and the European Commission's strategies on Digitising European Industry the pragmatical direction. To increase service interaction and system innovation within 
the regional innovation ecosystem, as identified in this article, base on a broad variety of activities and tasks that are captured under the dimensions of innovation networking, skills and training, innovation ecosystem and test before invest/investment. To perform the Hub's responsibilities, its activities and tasks, a tight cooperation and collaboration with stakeholders from business \& industry, government \& public administration, civil society \& users and research \& education (Quadruple Helix Stakeholders) is key for success. As identified (c.f. table 2), main stakeholders are business \& industry in close collaboration with research \& education. The cooperation and collaboration of these stakeholders is of major importance to successfully install the Hub as intermediate for increased service interaction and system innovation within the regional innovation ecosystem, including: the interaction and the sharing of resources (e.g. information and knowledge, pro-active value co-creation and system innovation) for increased value propositions. There are a variety of actions in preparation and range from tight relationship management with the co-creators and the SMEs, the collaborative organization and conduction of tailored events for digital innovation in SMEs, workshops on technology impact assessment and innovation, digital business modelling, employment patterns until the provision of services within the area of Artificial Intelligence, System/Ecosystem Collaboration and Resilience Engineering.

Acknowledgments. This article at hand was made possible by the financial support of Interreg Central Europe research project "4Steps" (Towards the application of Industry 4.0 in SMEs; project number: CE1492).

\section{References}

[1] European Commission, "European Digital Innovation Hubs in Digital Europe Programme,” Brussels (Belgium), Programme, 2021. [Online]. Available: https://ec.europa.eu/digital-single-market/en/digital-innovation-hubs-dihs-europe

[2] European Commission, "Shaping Europe's digital future: Digital Innovation Hubs (DIHs) in Europe,” 2021. https://ec.europa.eu/digital-single-market/en/digitalinnovation-hubs-dihs-europe

[3] F. Maurer, "Business Intelligence and Innovation: An European Digital Innovation Hub to Increase System Interaction and Value Co-creation within and among Service Systems," in Proceedings of the 10th International Conference on Operations Research and Enterprise Systems, Mar. 2021, pp. 208-217. [Online]. Available: https://www.scitepress.org/Link.aspx?doi=10.5220/0010255602080217

[4] M. Butter, "DIHNET," presented at the Opportunities and services provided by CSAs to support DIHs and EDIHs, digital, 2021. [Online]. Available: https://spaces.fundingbox.com/spaces/i4ms-i4ms-news/60587d999bbc1905d0abeb2a

[5] A. Tasig, "Roundtable on Digitising European Industry: Mainstreaming Digital Innovation Across All Sectors," European Commission, Brussels (Belgium), Report of Working Group $1, \quad 2017 . \quad$ [Online]. Available: https://ec.europa.eu/futurium/en/content/report-wg1-digital-innovation-hubsmainstreaming-digital-innovation-across-all-sectors-final

[6] A. Kalpaka, J. Sorvik, and A. Tassigiorgou, "***Digital Innovation Hubs as policy instruments to boost digitalisation of SMEs," European Commission, Brussels, 2020. [Online]. Available: https://ec.europa.eu/newsroom/dae/document.cfm?doc_id=66604 
[7] A. Kalpaka, J. Sörvik, A. Tasigiorgou, and G. Rissola, "Digital Innovation Hubs as policy instruments to boost digitalisation of SMEs," European Commission, Brussels (Belgium), JRS Science for Policy Report JRC121604, 2020. [Online]. Available: https://ec.europa.eu/jrc/en/publication/eur-scientific-and-technical-researchreports/digital-innovation-hubs-policy-instruments-boost-digitalisation-smes

[8] H. Chesbrough and J. Spohrer, "A Research Manifesto for Services Science," Commun $A C M$, vol. 49, no. 7, pp. 35-40, Jul. 2006, doi: 10.1145/1139922.1139945.

[9] H. W. Chesbrough, "Toward a New Science of Services," Harv. Bus. Rev., vol. 83, pp. 16-17, 43-44, Feb. 2005.

[10] J. Spohrer, P. P. Maglio, J. Bailey, and D. Gruhl, "Steps Toward a Science of Service Systems," IEEE Comput. Soc., vol. January 2007, pp. 71-78, Jan. 2007, doi: 0018-9162.

[11] S. L. Vargo and R. F. Lusch, "Evolving to a New Dominant Logic for Marketing," $J$. Mark., vol. Vol. 68, no. January 2004, pp. 1-17, Jan. 2004.

[12] S. L. Vargo and R. F. Lusch, "Service-dominant logic: continuing the evolution," $J$. Acad. Mark. Sci., vol. 36, no. 1, pp. 1-10, Mar. 2008, doi: 10.1007/s11747-007-0069-6.

[13] S. L. Vargo and M. A. Akaka, "Service-Dominant Logic as a Foundation for Service Science: Clarifications," Serv. Sci., vol. 1, no. 1, pp. 32-41, Mar. 2009, doi: 10.1287/serv.1.1.32.

[14] J. Spohrer and S. K. Kwan, "Service Science, Management, Engineering, and Design (SSMED): An Emerging Discipline - Outline \& References," Int. J. Inf. Syst. Serv. Sect., vol. 1(3), no. July-September 2009, pp. 1-31, 2009.

[15] S. Barile and F. Polese, "Smart Service Systems and Viable Service Systems: Applying Systems Theory to Service Science," Serv. Sci., vol. 2, no. 1-2, pp. 21-40, Jun. 2010, doi: $10.1287 /$ serv.2.1 2.21

[16] S. Alter, "Work System Theory: Overview of Core Concepts, Extensions, and Challenges for the Future," J. Assoc. Inf. Syst., vol. 14, no. 2, Feb. 2013, [Online]. Available: http://aisel.aisnet.org/jais/vol14/iss2/1

[17] S. L. Vargo, P. P. Maglio, and M. A. Akaka, "On value and value co-creation: A service systems and service logic perspective," Eur. Manag. J., vol. 26, no. 3, pp. 145-152, Jun. 2008, doi: 10.1016/j.emj.2008.04.003.

[18] W. Ganz, "Germany: Service Engineering," Commun ACM, vol. 49, no. 7, pp. 79-79, Jul. 2006, doi: 10.1145/1139922.1139954.

[19] G. Satzger et al., "Auf dem Weg zu einer Service Science: Perspektiven, Forschungsthemen und Handlungsempfehlungen aus der Sicht einer interdisziplinären Arbeitsgruppe," Mediendienstleistungen des Fraunhofer Informationszentrum IRB, $\begin{array}{llll}\text { Stuttgart, } 2010 . & \text { [Online]. }\end{array}$ https://www.ksri.kit.edu/downloads/WegServiceScience.pdf

[20] T. Böhmann, J. M. Leimeister, and K. Möslein, "Service Systems Engineering - A Field for Future Information Systems Research," Bus. Inf. Syst. Eng., vol. 6, no. 2, pp. 73-79, Jun. 2014, doi: DOI 10.1007/s12599-014-0314-8.

[21] P. P. Maglio and J. Spohrer, "Fundamentals of service science," J. Acad. Mark. Sci., vol. 36, no. 1, pp. 18-20, Jul. 2007, doi: 10.1007/s11747-007-0058-9.

[22] S. Barile and F. Polese, "Linking the Viable System and Many-to-Many Network Approaches to Service Dominant Logic and Service Science," Int. J. Qual. Serv. Sci., vol. Vol. 2, no. 1, pp. 23-42, 2010.

[23] S. L. Vargo, R. F. Lusch, and M. A. Akaka, "Advancing Service Scienceservice science with Service-Dominant Logicservice-dominant logic," in Handbook of Service Science, Springer, Boston, MA, 2010, pp. 133-156. doi: 10.1007/978-1-4419-1628-0 8.

[24] S. Barile, J. Pels, F. Polese, and M. Saviano, "An Introduction to the Viable Systems Approach and its Contribution to Marketing," J. Bus. Mark. Manag., vol. 2, pp. 54-78, Jun. 2012. 
[25] S. L. Vargo and R. F. Lusch, "It's all B2B... and beyond: Toward a systems perspective of the market," Ind. Mark. Manag., vol. 40, no. 2, pp. 181-187, Feb. 2011, doi: 10.1016/j.indmarman.2010.06.026.

[26] J. Spohrer, L. Anderson, N. Pass, and T. Ager, "Service science and service-dominant logic," in Otago Forum 2 (2008) - Academic Papers, Otago, 2008, vol. Paper no. 2. Accessed: $\quad$ Sep. 20, 2017. [Online]. Available: http://citeseerx.ist.psu.edu/viewdoc/download?doi=10.1.1.486.3642\&rep=rep1\&type=pd $\mathrm{f}$

[27] G. Rissola and J. Sörvik, "Digital Innovation Hubs in Smart Specialization Strategies," European Commission, Brussels (Belgium), JRC Technical Reports EUR 29374 EN, 2019. [Online]. Available: https://ec.europa.eu/jrc/en/publication/digital-innovationhubs-smart-specialisation-strategies

[28] G. Rissola and J. Sörvik, "Digital Innovation Hubs in Smart Specialisation Strategies," European Commission, Brussels (Belgium), JRC113111, 2018.

[29] AI DIH network, "What are digital innovation hubs," 2021. https://www.ai-dihnetwork.eu/project.html (accessed Mar. 25, 2021). 